\title{
Nursing teamwork and time to respond to call lights: an exploratory study
}

\author{
Beatrice Jean Kalisch ${ }^{1}$ \\ Aimee Elizabeth Labelle ${ }^{2}$ \\ Xie Boqin ${ }^{3}$
}

\begin{abstract}
Aim: The aim of this exploratory study was to determine whether the level of nursing teamwork is correlated to call light answering time in acute care hospital patient care units. Background: Teamwork has been shown to improve productivity. In this study, we examine the relationship between unit call light response time as a measure of productivity and the level of teamwork on the unit. Method: The Nursing Teamwork Survey was administered to nursing staff on 18 inpatient units in 3 hospitals. In addition to the overall teamwork score, the NTS has 5 subscales. Call light response times were collected from electronic systems which measures the time it takes for nursing staff on a given unit to respond to patient call lights. Results: There was no significant relationship between call light response time and teamwork overall or on the five subscales. Shared mental models, which comprise the conceptual understanding of the roles and responsibilities of each team member, however was moderately correlated with call-light answering times. Conclusions: It is logical that shared mental models would be associated with call light response time since a common problem in patient units is the "it's not my job syndrome" where nursing staff do not answer call lights for patients assigned to someone else. More research with a larger number of patient units is needed to validate these findings.

Descriptors: Hospital Communication Systems/Utilization; Safety Management; Nursing Care/ Utilization.
\end{abstract}

\footnotetext{
${ }^{1}$ PhD, Full Professor, School of Nursing, University of Michigan, USA.

${ }^{2} \mathrm{RN}, \mathrm{MSC}$

${ }^{3}$ Doctoral Student, School of Nursing, University of Michigan, USA.
} 


\section{Trabalho em equipe e tempo de resposta às chamadas de enfermagem: estudo exploratório}

Objetivo: o objetivo deste estudo exploratório foi determinar se o nível de trabalho em equipe de enfermagem está correlacionado ao tempo de resposta às chamadas de pacientes, em unidades de hospitais de tratamento intensivo. Antecedentes: tem sido reportado que o trabalho em equipe melhora a produtividade. A relação entre o tempo de resposta às chamadas de enfermagem foi examinada neste estudo como uma medida da produtividade e do nível de trabalho em equipe, na unidade. Método: o Nursing Teamwork Survey foi administrado nas equipes de enfermagem de 18 unidades de internação, em três hospitais. Além da pontuação global do trabalho em equipe, o instrumento tem cinco subescalas. O tempo de resposta às chamadas de enfermagem foi coletado nos sistemas de chamadas de enfermagem que registram o tempo que a equipe de enfermagem, em uma determinada unidade, leva para atender as chamadas dos pacientes. Resultados: a relação entre o tempo de resposta às chamadas de enfermagem e a pontuação global do trabalho em equipe ou as pontuações das cinco subescalas não foi significante. Entretanto, os modelos mentais compartilhados, que compreendem o entendimento conceitual dos papéis e responsabilidades de cada membro da equipe, foram moderadamente correlacionados ao tempo de resposta às chamadas da campainha. Conclusões: parece lógico que os modelos mentais compartilhados estariam associados ao tempo de resposta às chamadas já que um problema comum em unidades hospitalares está relacionado à "síndrome: este não é meu trabalho", ou seja, o pessoal de enfermagem não responde às chamadas de pacientes que não estão sob sua responsabilidade. Mais estudos com número maior de unidades hospitalares são necessários para validar estes resultados.

Descritores: Sistemas de Comunicação em Hospital/Utilização; Gerenciamento de Segurança; Cuidado de Enfermagem/Utilização.

\section{Trabajo en equipo y tiempo de respuesta al timbre del paciente: un estudio exploratorio}

Objetivo: La finalidad de estudio exploratorio fue determinar si el nivel de trabajo en equipo de enfermería tiene correlación con el tiempo de espera de atención al timbre del paciente en unidades de internación hospitalaria para cuidados intensivos. Antecedentes: Se ha demostrado que el trabajo en equipo mejora la productividad. El presente estudio investigó la relación entre tiempo de respuesta de la unidad a la atención del llamado del paciente como medida de productividad y del nivel de trabajo en equipo en la unidad. Método: El instrumento Trabajo en Equipo de Enfermería fue utilizado con el personal de enfermería de tres hospitales. Además de la puntuación total, el instrumento cuenta con 5 sub-escalas. El tiempo de respuesta al timbre del paciente fue registrado en los sistemas informáticos que miden el tiempo necesario para que el personal de enfermería de una determinada unidad atienda a la llamada del timbre del paciente. Resultados: No hubo relación significativa entre el tiempo de respuesta al timbre y el puntaje global del trabajo en equipo o los puntajes de las cinco sub-escalas. Mientras tanto, modelos mentales compartidos, que comprenden el entendimiento conceptual de los papeles y responsabilidades de cada miembro del equipo, fueron moderadamente correlacionados con el tiempo de respuesta al llamado del timbre. Conclusiones: Es lógico que los modelos mentales compartidos estén asociados al tiempo de respuesta al llamado, ya que un problema común en unidades de internación es el "síndrome de ese no es mi trabajo", en el cual el personal de enfermería no responde al timbre de los pacientes que no tienen asignados. Se necesita de más investigaciones en un número mayor de unidades de internación de pacientes para validar estos resultados.

Descriptores: Sistemas de Comunicación en Hospital/Utilización; Administración de Seguridad; Atención de Enfermería/Utilización. 


\section{Introduction}

Since the early $20^{\text {th }}$ century, nurse call light systems have provided hospital patients with an essential communication link with their caregivers. To hospital inpatients, the call light is the primary method of contacting staff and therefore represents the most basic tool for patient empowerment. It gives patients environmental control during the stressful event of hospitalization. It is also a basic safety tool, allowing patients to communicate their needs to staff whether they require routine assistance or have an acute change in condition. Inpatients trust that when they use a call light device, someone will respond to it in a timely manner. Because call light systems are used to communicate patient needs to staff, the prompt answering of call lights directly affects patient satisfaction and perceptions of quality ${ }^{(1)}$. Surprisingly, little research has been conducted regarding how call light systems are used by patients and responded to by nursing staff members.

For nurses, the call light provides some degree of reassurance that their patients will have the ability to contact them when a need for assistance arises. Unfortunately, the call light can also represent an interruption in workflow for nursing staff. Frequent call light requests can create a backlog of tasks for a nurse or nursing assistant attempting to get through a shift. When a call light is activated, a nurse must try to prioritize if the task at hand is the most important one, or if the call light or perhaps even other call lights need to be responded to first. In reality, one caregiver alone cannot meet the needs of multiple patients and competing call lights. Nursing staff on a patient care unit need to work together as a team to care for patients including responding in a timely manner to call light requests $^{(2-3)}$.

With the primary and total patient care models (care provided by one nurse), much emphasis has been placed on individual nurses and how they care for a patient and less acknowledgement is given to that fact that nurses should be working in teams to complete their work. Recent work on nursing teamwork has uncovered the importance of teamwork on patient safety and staff satisfaction (2,4-5). No one however has utilized response time to call lights as an indicator of nursing productivity and correlated it to the level of nursing teamwork. In this study, we explore the relationship between level of nursing teamwork and time to answer patient call lights.

\section{Background studies}

\section{Call lights}

In 2006, Deitrick and colleagues published an ethnographic study of the use of call lights in a 36 bed medical surgical unit. The authors state that anyone who has spent time in a hospital knows that the call bell is the patients' lifeline. It is perhaps one of the few means of control that patients have over their situation. Attention has been paid in the literature to the nature of patient call light requests. Van Handel and Krug(6) studied the call light requests on an adult orthopedic unit and found the primary reasons for call light use were requests for toileting assistance, repositioning and pain medications or to retrieve another item. In 2009, Tzeng(1) published research conducted on 27 adult patient care units in four hospitals. She found that the primary reasons for patient initiated call lights were for toileting assistance, pain medication and intravenous therapy issues.

A significant portion of the call light research and their usage focuses on the device as a tool for patient safety. One study showed that on surgical units, when call light use was high, the patient injurious fall rate was

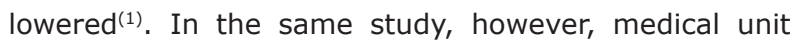
patient fall rates were not significantly related to more frequent use of call lights ${ }^{(1)}$. Meade and colleagues(7) found that the incorporation of hourly nursing rounds on nursing units lead to both a decreased use of call lights and a decreased patient falls by anticipating patients' needs. Similarly, a study by Athwal and colleagues(8) concluded that improvements in communication during change of shift reports led to the reduction of patient call light usage.

In 2008, Tzeng and Yin $^{(9)}$ reviewed the quantitative and qualitative data collected on the incidence of falls between 2005 and 2006 in an adult medical unit. The researchers concluded that patient-nurse communication broke down in $17.06 \%$ of the falls that occurred, making it the most common extrinsic risk factor for patient falls in that unit. Call lights not being answered on time (meaning quickly enough to meet the needs of an individual patient) were found to be contributing factors to a significant number of falls on the unit(9).

Response to call lights has also been associated with patient satisfaction. Dietrick and colleagues ${ }^{(10)}$ found that there were delays in answering call lights, and at other times a light was answered but the patient's request was not followed through on. Frustration regarding delays in answering the lights was one of the most frequent comments made by patients in interviews. They 
concluded that understanding the importance of the call light to patients is key to improving patient satisfaction. Others have also found that call light response time is related to patient satisfaction ${ }^{(1,7)}$.

Another perspective of the reviewed research on call light usage involves nurses' perspective on call lights and their use. According to Dietrick, busy caregivers can find answering call lights to be time consuming, and some patients who frequently use call lights may be viewed as "pests." Meade ${ }^{(7)}$ concluded that call lights "can impose considerable demands on nurses' time"(10). Tzeng(1) quantified nurses' perceptions of call lights in 27 adult care units. In that study, $49 \%$ of staff perceived that patient initiated calls mattered to patient safety, $77 \%$ agreed that these calls were meaningful, 52\% thought that the call required attention by nurses, but at the same time, $53 \%$ of nurses felt that call lights prevented them from doing the critical aspects of their work.

\section{Nursing teamwork}

The definition of teamwork utilized in this study was a group of two or more people working interdependently to achieve a common goal(11). Teamwork has been studied in many sectors of business and industry and has been noted to be an essential component of high performance work organizations ${ }^{(12)}$. Validation of the positive effects of teamwork has come from workplaces in varied sectors of business and industry ${ }^{(13)}$.

Research from the airline industry determined that the majority of aviation accidents were caused by failures in communication and teamwork. Crew Resource Management is an educational program designed to improve the safety of air travel though teamwork training and is mandated for pilots worldwide. It has been proven to be effective in reducing human error in flight. The Institute of Medicine (IOM) ground breaking report "To Err is Human" cited evidence that at least 44,000 and perhaps as many as 98,000 deaths a year have been caused by medical errors. This report pointed to enhanced teamwork as way to reduce errors in the healthcare system ${ }^{(14)}$.

Since the IOM report was first published, the importance of teamwork in healthcare has grown. Most of the research relating to the reduction of errors in healthcare through improving teamwork however has taken place in specialty areas such as the operating room, emergency rooms, intensive care units and emergency and trauma teams ${ }^{(15)}$. Leonard and colleagues found that teamwork initiatives reduced wrong-site surgeries, improved continuity of care for patients transferred from the hospital to skilled nursing facilities, reduced nurse turnover and improved critical responses to perinatal emergencies ${ }^{(16)}$. Pronovost and colleagues documented research that links the increased use of teamwork principles in intensive care units to a reduction in error $^{(17)}$.

There have been fewer studies of nursing teamwork in inpatient hospital units. Kalisch, Weaver and Salas ${ }^{(2)}$ completed a qualitative study with nursing staff, which highlighted what teamwork looks like when it occurs. Higher self-identified teamwork in the intensive care unit was found to be related to lower mortality rates ${ }^{(18)}$. It was found that lower vacancy rates and turnover were associated with a higher level of teamwork while another study showed that when teamwork is good, staff satisfaction is higher ${ }^{(4)}$. An investigation by Brewer (19) showed that a group-type hospital culture predicted fewer patient falls with injury. An intervention to enhance nursing staff teamwork was tested which took place on a 41-bed oncology unit with 55 nursing staff members(20). The intervention resulted in a significant decrease in patient falls, a reduced turnover and vacancy rate and higher staff evaluations of teamwork on their unit(20). Staffing has been found to predict the level of teamwork ${ }^{(21)}$. A cross-sectional study to examine the relationship among hospital and staff characteristics and nursing teamwork showed that job title, shift, absenteeism, perceived adequacy of staffing, and unit type were significant predictors of teamwork ${ }^{(5)}$.

No studies were found which addressed the relationship between levels of teamwork and time to respond to call lights. This exploratory study examines this relationship.

\section{Research questions}

The study questions are as follows:

1) Does call light response time vary by hospital and/or type of patient care unit?

2) What is the relationship between teamwork overal and the elements of teamwork (i.e. team leadership, team orientation, back up, shared mental model, and trust), and response time to patient call lights?

\section{Conceptual Framework}

The theoretical framework for this study adapted a teamwork model developed by Salas and colleagues $^{(22)}$. As can be seen in Figure 1, they identify five core components of teamwork: team leadership (i.e. structure, direction and support provided), team 
orientation (i.e. cohesiveness and awareness of the work group as a team), mutual performance monitoring (i.e. observing and monitoring one another), back up behavior (i.e. helping each other in completing tasks) and adaptability (i.e. ability to adjust to changes in the work environment). They also identify three coordinating mechanisms: shared mental model (i.e. collective mindset), closed loop communication (i.e. receipt of the information is verified by the sender and receiver) and mutual trust (i.e. belief that team members will act in a way that furthers the aims of the team in reaching their goals).

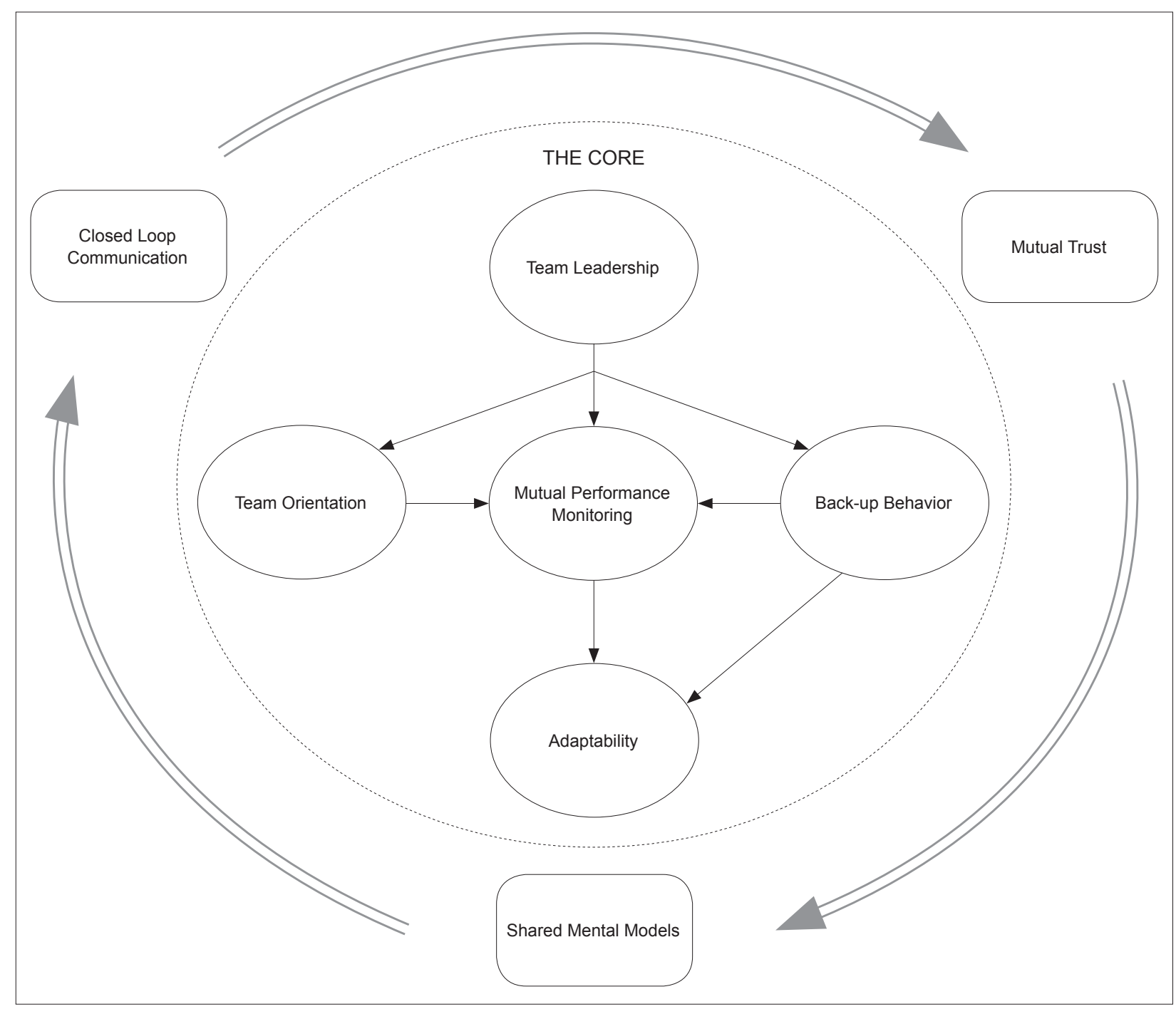

(Reprinted with permission from Salas, Sims, \& Burke, 2005)

Figure 1 - The "Big Five" framework of teamwork

However a study of nursing staff in inpatient settings demonstrated that five of these elements were evident in this population: team leadership, team orientation, back up, shared mental model, and trust(11). Thus these five elements of teamwork were utilized in this study.

\section{Study Methods}

\section{Sample}

To be eligible for participation in this study, hospitals had to have a call light tracking system. Three hospitals were selected and IRB approval was obtained in each facility. A total of 14 medical-surgical and intermediate/ step down patient care units within the three participating hospitals made up the sample. Two of the study hospitals were community-based facilities and a third was a university healthcare center. Hospital 1 had 3 participating units while Hospital 2 had 5 and Hospital 3 had 6 units in the study. The sample was made up of $26.9 \%$ intermediate/step down and $73.1 \%$ medical surgical units. 


\section{Measures}

\section{Call light response time}

Call light answering time was recorded by the patients' room call light tracking system. The patient call light system refers to the call light that a patient uses in their room, either from the bed, bedside chair or commode. The system electronically records each call light request for assistance and number of seconds it takes for the call light to be answered. It does not record when a request made by a patient is fulfilled. Although it did not happen in this study, if a power outage or other system disruption occurred and the call lights failed to record, we would have adjusted the data to reflect only those days in the month where the light systems were functioning normally. Total call light use by unit per month was derived with the following computation:

[(Counts of total call light use / Number of covered days) $x$ Total number of covered days]

Total patient days for the month

The average response time in seconds for the month of the study was utilized.

\section{Nursing Teamwork}

The Nursing Teamwork Survey (NTS) was utilized to determine the level of teamwork on each patient care unit ${ }^{(11)}$. The survey was administered to the nursing staff (nurses, nursing assistants and unit secretaries) on each unit in the same month that the call light response time was collected. Measures of content, criterionrelated (concurrent) and construct (contrast-group and convergent) validity yielded positive results. Content validity was established by a panel of experts. Concurrent validity showed significant correlation between teamwork scores and an imbedded question related to overall satisfaction with teamwork $(r=0.633, p<.001)$. The exploratory factor analysis on a random half of the sample predicted a 33-item five factor solution while the confirmatory factor analysis on the remaining half of the sample confirmed the factor structure (CFI=0.884, RMSEA =.055, SRMR=.045). Contrast group validity showed that a non-inpatient unit did not answer the questions in the same way $\left(r_{w g(j)}=0.25\right)$ as the inpatient units $\left(r_{w g(j)}>0.90\right)$. Convergent validity of the teamwork tool was measured with correlations with the teamwork subscale of the Safety Attitudes Questionnaire $(r=0.76$, $p=.01)$. The NTS demonstrated good test-retest reliability $(r=0.92, p<.05)$ and internal consistency $(\alpha=0.94)$. The NTS contains a total of 33 questions with each question being answered on a five point Likert response scale ( $1=$ rarely, $2=25 \%$ of the time, $3=50 \%$ of the time, $4=75 \%$ of the time and $5=$ always).

The NTS was placed in $9 \times 11$ inch envelops, along with a cover letter explaining the study, their right to not participate, the assurance of anonymity and a candy bar as a token of appreciation. These envelopes were placed in staff members' mailboxes. Follow up reminders were given using posters on the units.

All responses were anonymous. Staff members placed their completed surveys in a sealed envelope and then into a locked box on their unit. Once a response of $50 \%$ was achieved for the unit, the staff was provided a pizza party. Nursing teamwork surveys were given to all nursing staff on the study units. A total of 889 surveys were received, representing a response rate of $60 \%$. Eleven surveys were eliminated from the pool of valid surveys because of incomplete answers or because those responders did not regularly work in the unit surveyed.

\section{Data Analysis}

NTS data was entered into SPSS statistical software, version 16 . The level of analysis for this study was the patient care unit. There were six teamwork variables: overall teamwork, trust, team leadership, team orientation, back up, and shared mental model. The overall teamwork score was calculated as an average of all of the subscales. A score for each of these teamwork variables was calculated at the patient unit level.

After preliminary analyses, call light response time was a non-normal distribution and linearity between call light response time and teamwork variables were violated. Thus, Spearman's Rank Order Correlations were performed to test the relationship among study variables-call light response time and the five teamwork subscales and the overall teamwork score for each unit. Average call light time in seconds for the unit for the month were calculated and compared with unit-level teamwork subscales and overall teamwork scores.

The Kruskal-Wallis test was performed to test if response time varied by hospitals. ANOVA was 
conducted to assess 6 teamwork variables in the three different facilities to determine if there were statistically significant differences among them. To compare the intensive care with the non intensive care units, a MannWhitney $U$ test was employed.

\section{Study Results}

RNs made up $68 \%$ of the respondents to the NTS while $22 \%$ were nursing assistants and $6.5 \%$ were unit secretaries. They were predominately female and under the age of 55 years. About half of the respondents had five years or less experience, and $60 \%$ were educated at the associate degree or lower level. In terms of age, $37 \%$ were under age of 35 years.

\section{Call light response time by hospital}

The median of overall response time was 216 seconds and the average response time was 348.29 seconds. There was a non-significant difference in response time among the three hospitals $\left(\chi^{2}(2,14)=3.54\right.$, $p=0.17)$. Hospital 3 nursing staff took the longest time (Mean=548.33) answering call lights compared to Hospital 1(Mean=203.3) and Hospital 3 (Mean=195.2). The medians for call light answering time were: Hospital 1=191 seconds, Hospital 2=215 seconds, and Hospital $3=584.5$ seconds.

\section{Teamwork by hospital}

The differences of 6 teamwork variables were showed in Table 1. Hospital 3 had the significantly highest overall teamwork score. There was a significant difference in team leadership across the three hospitals $(p=.002)$ and Hospital 3 reported the highest team leadership score (Mean=3.69) than the other two, which had mean values of 3.22 and 3.33, respectively. No significant difference was found among trust, team orientation, backup and shared mental model.

Table 1 - Differences of teamwork across hospitals

\begin{tabular}{|c|c|c|c|c|c|}
\hline Variable & $\begin{array}{c}\text { Hospital } 1 \\
\text { (Mean } \pm S D)\end{array}$ & $\begin{array}{c}\text { Hospital } 2 \\
\text { (Mean } \pm S D)\end{array}$ & $\begin{array}{l}\text { Hospital } 3 \\
\text { (Mean } \pm S D)\end{array}$ & $\mathbf{F}$ & $p$ \\
\hline Overall teamwork & $3.25 \pm 0.11$ & $3.24 \pm 0.08$ & $3.50 \pm 0.17$ & 6.492 & 0.014 \\
\hline Trust & $3.35 \pm 0.26$ & $3.29 \pm 0.09$ & $3.40 \pm 0.11$ & 0.585 & 0.573 \\
\hline Team Orientation & $3.18 \pm 0.22$ & $3.22 \pm 0.18$ & $3.27 \pm 0.24$ & 0.197 & 0.824 \\
\hline Backup & $3.14 \pm 0.34$ & $3.21 \pm 0.14$ & $3.45 \pm 0.22$ & 2.634 & 0.116 \\
\hline Shared Mental Model & $3.86 \pm 0.19$ & $3.86 \pm 0.11$ & $3.87 \pm 0.17$ & 0.010 & 0.990 \\
\hline Team leadership & $3.22 \pm 0.13$ & $3.33 \pm 0.20$ & $3.69 \pm 0.12$ & 11.978 & 0.002 \\
\hline
\end{tabular}

\section{Response time and teamwork}

The results of the analysis of the correlations among trust, team orientation, backup, shared mental model, team leadership and overall unit teamwork and response to call light time were performed. Three elements of teamwork--trust, team orientation and shared mental model-- showed a degree of negative correlation; that is, the higher the teamwork scores, the lower the call light answering times. However, these relationships were not significant. Shared mental model demonstrated the highest correlation to call light answering time but it did not reach a significant level $(r=-334, p=.243)$. Back up behaviors, team leadership and teamwork overall demonstrated no significant relationship to call light answering time.

\section{Discussion}

This exploratory study examined the relationship between call light answering response time and nursing teamwork. No significant differences were found between nursing teamwork overall and the five subscales of teamwork and call light answering time. One subscale, shared mental models (referring to the extent that team members have the same understanding of who is to do what and when) had the highest correlation to shorter response times to call lights.

The fact that the strongest correlation was between shared mental model (conceptual understanding of the roles and responsibilities of each team member) and response time fits with findings of other studies we have conducted how nurses work. Nursing staff members often do not answer call lights for patients not assigned to them(23). This is referred to as "it's not my job syndrome," and we have found that it is common in acute care hospital patient care unit teams. Dietrick et al. ${ }^{(10)}$ observed that "the first and most problematic issues in call light issue is that of answering the light includes [deciding] whose job it is to answer the bells" It is logical that working together as a team to care for 
all the patients on a unit would enable nursing staff to respond to call lights faster.

Since the trends are in the direction of a relationship between call light response time and teamwork, repeating this study with a larger sample size of units may yield significant results. Other important variables need to be added to the study such as staffing levels, physical layout of the units, amount of experience of the staff, patient acuity and others

\section{Study Limitation}

This exploratory study was limited by the number of patient units and hospitals included in the study, which does not allow for generalization of the study findings. A larger scale study may yield different results. Another limitation is that because this was an exploratory study, we did not collect staffing levels, physical layout of the unit, patient acuity and other potentially important variables for the study. Teamwork was measured by self reports of the staff (who completed surveys) as opposed to observations of teams in action. On the other hand, reliably capturing team behaviors through observation has proven to be a difficult process, requiring multiple trained observers with extensive training.

\section{References}

1. Tzeng $\mathrm{H}$, Yin $\mathrm{C}$. Are call light use and response time correlated with inpatient falls and inpatient dissatisfaction? J Nurs Care Qual. 2009;24(3):232-42.

2. Kalisch B, Weaver S, Salas E. What does nursing teamwork look like? A qualitative study. J Nurs Care Qual. 2009;24(4):298-307.

3. Kalisch B, Schoville R. It takes a team. Am J Nurs. In press.

4. Kalisch B, Lee $H$, Rochman M. Nursing staff teamwork and job satisfaction. J Nurs Manage. 2010;18:938-47.

5. Kalisch B, Lee K. Variations of nursing teamwork by hospital, patient unit, and staff characteristics. Appl Nurs Res. In press.

6. Van Handel K, Krug B. Prevalence and nature of call light requests on an orthopaedic unit. Orhtop Nurs.1994;13(1):13-20.

7. Meade $C M$, Bursell $A L$, Ketelson L. Effects of nursing rounds on patients call light use, satisfaction and safety. Am J Nurs. 2006;106(9):58-70.

8. Athwal P, Fields W, Wagnell E. Standardization of Change-of-Shift Report. J Nurs Care Qual. $2009 ; 24(2): 143-7$

9. Tzeng $\mathrm{H}$, Yin $\mathrm{C}$. The extrinsic risk factors for inpatient falls in hospital patient rooms. J Nurs Care Qual. 2008;25(3):233-41.

10. Deitrick L, Bokovoy J, Stern G, Panik A. Dance of the call bells: using ethnography to evaluate patient satisfaction with quality of care. J Nurs Care Qual. 2006;21(4):315-24.

11. Kalisch B, Lee $H$, Salas E. The development and testing of the Nursing Teamwork Survey. Nurs Res. 2010;59(1):42-50.

12. European Forum for the Improvement of Living and Working Conditions. Teamwork and high performance work organizations. [internet]. 2007; [acesso 15 maio 2010sponível em:. http://www.eurofound.europa.eu/ ewco/reports/TN0507TR01/TN0507TR01.pdf

13. Conger JA, Lawler E.E.III. Sharing leadership on corporate boards: a critical is its ability to act as a team. Org Dynamics. 2009;38(3):183-91.

14. Kohn JT, Corrigan JM, Donaldson MS, editors. To Err is Human: Building a Safer Health System. Washington

DC: Institute of Medicine National, National Academy Press; 2000.

15. Mansor T. Teamwork and patient safety in dynamic domains of healthcare: a review of the literature. Acta Anaesthesiol Scand. 2009;53:143-51.

16. Leonard M, Graham S, Bonacum D. The human factor: the critical importance of effective teamwork and communication in providing safe patient care. Qual Safety Healthcare. 2004;13:185-90.

17. Pronovost PJ, Berenholtz SM, Goeshel C, Thom I, Watson SR, Holzmueller CG, et al. Improving patient safety in intensive care units in Michigan. J Crit Care. 2008;23(2):207-21.

18. Whellan SA, Burchill CN, Tilin F. The link between teamwork and patients' outcomes in intensive care units. Am J Crit Care. 2003;12(6):527-34.

19. Brewer BB. Relationship among teams, culture, safety, and cost outcomes. Western J Nurs Res. 2006;28(6):641-53.

20. Kalisch B, Curley M, Stefanov S. An intervention to enhance nursing staffnteamwork and engagement. J Nurs Admin. 2007;37(2):77-84.

21. Kalisch B, Lee K. Nurse staffing levels and teamwork: A cross sectional study of patient care units in acute care hospitals. J Nurs Scholarship. 2011;43(1):82-8.

22. Salas E, Sims DE, Burke CS. Is there a "Bib Five" in teamwork? Small Group Res. 2005;36(5):555-9.

23. Kalisch B. The impact of RN-UAP relationships on quality and safety. Nurs Manage. 2011;42(9):16-22.

Received: Aug. 23 2012 Accepted: Oct. $1^{\text {st }} 2012$ 